\title{
Gravity analysis of the offset between crustal structure and topography in the Liupan Shan, northeast Tibetan Plateau
}

\author{
Zhenyu Wang ${ }^{1}$ and Guangyu Fu ${ }^{2^{*}}$ (B)
}

\begin{abstract}
Dense gravity/GPS measurements collected around the southwest margin of the Ordos Block in 2014 and 2017 were used to obtain three gravity anomaly profiles across the Liupan Shan Mountains. The Liupan Shan is located in a Bouguer gravity anomaly (BGA) transitional zone; however, low BGAs to the west do not correspond to the topography of the Liupan Shan in that region, with a maximum offset of approximately $34 \mathrm{~km}$. This offset is also found in inverted crustal density structures whereby the interface between the upper and lower crust is notably concave to the west of the Liupan Shan. Flexural analysis indicates that the effective elastic thickness is $5 \mathrm{~km}$ and the uplift is caused by oblique subduction of surface materials. According to this uplift mechanism, the offset suggests that Liupan Shan migrated eastward following partial isostatic compensation. Therefore, we suggest that Liupan Shan has experienced an uplift-compensation-uplift tectonic process.
\end{abstract}

Keywords: Bouguer gravity anomaly, Liupan Shan, Crustal structure, Flexure analysis, Uplift mechanism

\section{Introduction}

As the highest, youngest, and most active geological zone on Earth, the Tibetan Plateau has been widely and thoroughly studied in the area of geophysics, geochemistry, and geology. Uplift and expansion of the Tibetan Plateau is caused by subduction of the Indian subcontinent beneath the Eurasian continent, which also resulted in the formation of a large number of strike-slip and thrust faults (Molnar and Tapponnier 1975). Subduction processes have substantially affected the landscape, climate, and biological species of the Tibetan Plateau (Kutzbach et al. 1993). Moreover, studying the uplift mechanism of the Tibetan Plateau can deepen our understanding of tectonic collision processes.

The Liupan Shan orogeny (Fig. 1), which embodies uplift in the northeast Tibetan Plateau, can be regarded

\footnotetext{
*Correspondence: fugy@cea-ies.ac.cn

${ }^{2}$ Institute of Earthquake Forecasting, China Earthquake Administration, Beijing 100081, China

Full list of author information is available at the end of the article
}

as a far-field effect of continental collision (Zhang et al. 1991). Although the precise uplift mechanism is debated, the following coexisting end-member models have been proposed: (1) oblique subduction of surface materials (Tapponnier et al. 2001); (2) lower crustal flow (Royden et al. 1997); and (3) migration of mantle materials (England and Houseman 1989). These models are supported by evidence from seismological (Shen et al. 2017), thermochronological (Wang et al. 2011), magnetic (Wu et al. 2019), and gravity analyses (Wang et al. 2014). Uplift mechanisms can be studied using the gravity admittance method, which can calculate the initial loading ratio to reveal the loading source in the lithosphere (McKenzie 2003). However, there are few related studies on the Liupan Shan area because modeling results are often unconvincing and field analyses are typically unfeasible.

The aim of this study is to reveal the uplift mechanism of the Liupan Shan through an analysis of in situ gravity measurements around the southwest margin of the Ordos Block in 2014 and 2017. We then perform data processing and reveal that Bouguer gravity anomalies 


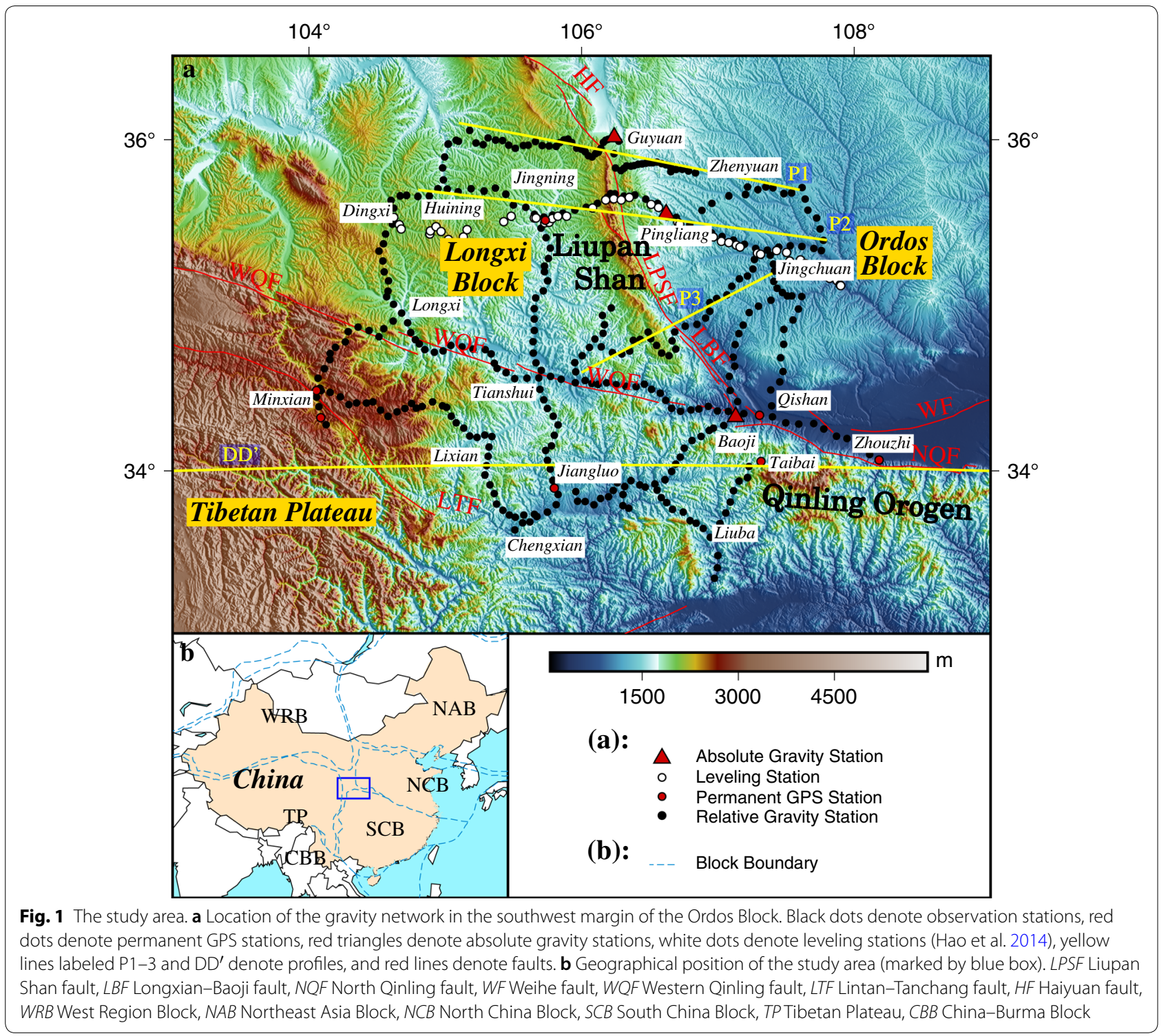

(BGAs) are relatively low to the west of the Liupan Shan. This anomaly is consistent with the uplift mechanism revealed by flexural analysis, suggesting that initial loading of the Liupan Shan area is from the oblique subduction of surface materials. This work may shed light on the tectonic evolution of Liupan Shan.

\section{Tectonic setting}

The Liupan Shan separates the stable Ordos Block from the severely thrusted Longxi Block, which in turn is separated by the Western Qinling fault from the Tibetan Plateau (Fig. 1). Thrusting of the Tibetan Plateau resulted in uplift of the Longxi Block and formation of abundant folds between 11.8 Ma and $7 \mathrm{Ma}$ (Liang et al. 2014). The stable Ordos Block is located on the west of the North
China Block and characterized by thick lithosphere, an absence of earthquakes, and an apparent lack of internal deformation since the late Paleoproterozoic (Wan et al. 2013). To the south of the study area is the Qinling Orogen, whose eastern and western parts have been uplifted by subduction of the North and South China Blocks and lower crustal flow from the Tibetan Plateau, respectively. The Qinling Orogen is relatively complex because it is situated at the conjunction zone of three main tectonic blocks (Wang et al. 2018).

The study area experienced significant deformation in the late Cenozoic and is currently affected by activity along the Liupan Shan fault, which is connected in the north to the eastern part of the Haiyuan fault (Zheng et al. 2006). The Haiyuan fault is a left-lateral strike-slip 
fault with a horizontal slip component of $4.1 \pm 1.2 \mathrm{~mm} / \mathrm{a}$, according to GPS measurements. The Liupan Shan fault shows almost no left-lateral strike-slip component, and the horizontal thrust component of $2.9 \pm 1.2 \mathrm{~mm} / \mathrm{a}$. A major part (70\%) of the slip component of Haiyuan fault converts to the thrust component of Liupan Shan fault, but a minor part (30\%) is absorbed by the Liupan Shan fault, leading to uplift ( $\mathrm{Li}$ et al. 2017). The southern part of the Liupan Shan fault is connected to the left-lateral strike-slip Longxian-Baoji fault.

Under the thrust action of the Longxi Block, the Liupan Shan Block experienced intense plate convergence and uplift in the late Cenozoic, which occurred along with deep incision of rivers and the appearance of typical eolian red clay (Song et al. 2001). The initial uplift of the Liupan Shan, its adjacent area, and the Tibetan Plateau is linearly distributed (Harrison et al. 1992), indicating that the main cause of uplift was expansion of the Tibetan Plateau.

\section{Data processing}

Gravity and GPS data used in this study were obtained from in situ observations conducted in 2014 and 2017 (Wang et al. 2018). Normal correction, free-air correction, Bouguer correction, and terrain correction were performed on the adjusted gravity data to obtain complete BGA (Fig. 2). GPS measurements are used in both the free-air correction and Bouguer correction. The high accuracy and resolution GDEMV2 model, released by the Chinese Academy of Science (http://www.gsclo ud.cn), and the valid method proposed by Fu et al. (2014) are used in the terrain correction. According to isostasy theory, BGAs are typically low in high-altitude areas due to the existence of the mountain root, whereas those in ocean or basin areas are high. The altitude of the Longxi Block (west) is higher than that of the Ordos Block (east). The mean BGAs in the western part are $-216.7 \mathrm{mGal}$, $-231.3 \mathrm{mGal}$, and $-193.5 \mathrm{mGal}$ for each profile (P1P3), whereas those in the eastern part are $-185.3 \mathrm{mGal}$, $-167.9 \mathrm{mGal}$, and $-170.4 \mathrm{mGal}$, respectively; thus, the gravity results conform to the theory. The Liupan Shan is located in the transitional zone between high and low BGAs. However, low BGAs do not correspond to the highest altitudes in the Liupan Shan (Fig. 2); i.e., the three lowest BGAs are observed to the west of the Liupan Shan, indicating that these abnormal results occur throughout the entire region. This phenomenon is clearest in profile P2 across the middle of the Liupan Shan, where the offset between the peak altitude in the Liupan Shan and low BGA values is $34 \mathrm{~km}$.

In order to evaluate the cause of this offset, we inverted the crustal density structure. For avoiding the multiple solutions of gravity inversion, joint inversion of gravity and seismology was performed. The inversion procedure was as follows:

1. Take the seismic velocity result of a profile as the initial model and convert velocity to density according to empirical formulas.

2. Calculate the modeled BGAs of the initial model using the two-dimensional body method (Talwani et al. 1959) and compare them with the observed BGAs. If the misfit exceeds the threshold, then perform step 3; otherwise, proceed to step 4.

3. Invert the density structure using the non-linear least squares algorithm (Marquardt 1963) with constraints of the measurements, then repeat step 2 .

4. Accept the model.

There are infinitely many models that reduce the misfit to a desired value in gravity inversion. To find a particular model, an efficient and popular method is to require that the inverted model is close to a reference model ( $\mathrm{Li}$ and Oldenburg 1998). We adjusted the model slightly according to the BGAs once the initial model was determined. Therefore, the initial model was crucial (see Additional file 1). In this study, we transferred the velocity structure of profile DD' from Bao et al. (2013), located in the center of the study area, to the density structure using Eq. 1, which was obtained from the relationship between velocity and density in the CRUST1.0 model (Laske et al. 2013):

$$
\rho=0.0562 \times v_{\mathrm{s}}^{2}+0.0472 \times v_{\mathrm{s}}+1.9265,
$$

where $\rho$ is the density and $v_{\mathrm{s}}$ is the $\mathrm{S}$-wave velocity. The density structure required further processing but was not used directly as the initial model because it was located $2^{\circ}$ from the profile P2. We assumed that the structures of two profiles located $0.1^{\circ}$ apart were similar; therefore, the density structure of a profile could be used as the initial model for another profile located $0.1^{\circ}$ apart. Through this "profile propagation" method, we gradually propagated to profiles P2 and P3 from profile DD'. The initial model of profile P3 could not be obtained by this method because P3 does not trend in the EW direction. Instead, it was interpolated using the inverted density structures of other profiles.

Overall, folds in the shallow crustal structure correspond to fluctuations in BGAs, whereas variations in the deep crustal structure correspond to larger trend of BGAs. Misfits between the observed BGAs and modeled BGAs (Fig. 2) for profiles P1, P2, and P3 are $1.7 \mathrm{mGal}, 1.9$ $\mathrm{mGal}$, and $3.2 \mathrm{mGal}$, respectively. The misfit reflects the reliability of the inversion result and generally does not exceed $5 \mathrm{mGal}$ (Zhang et al. 2017). The inverted structure 


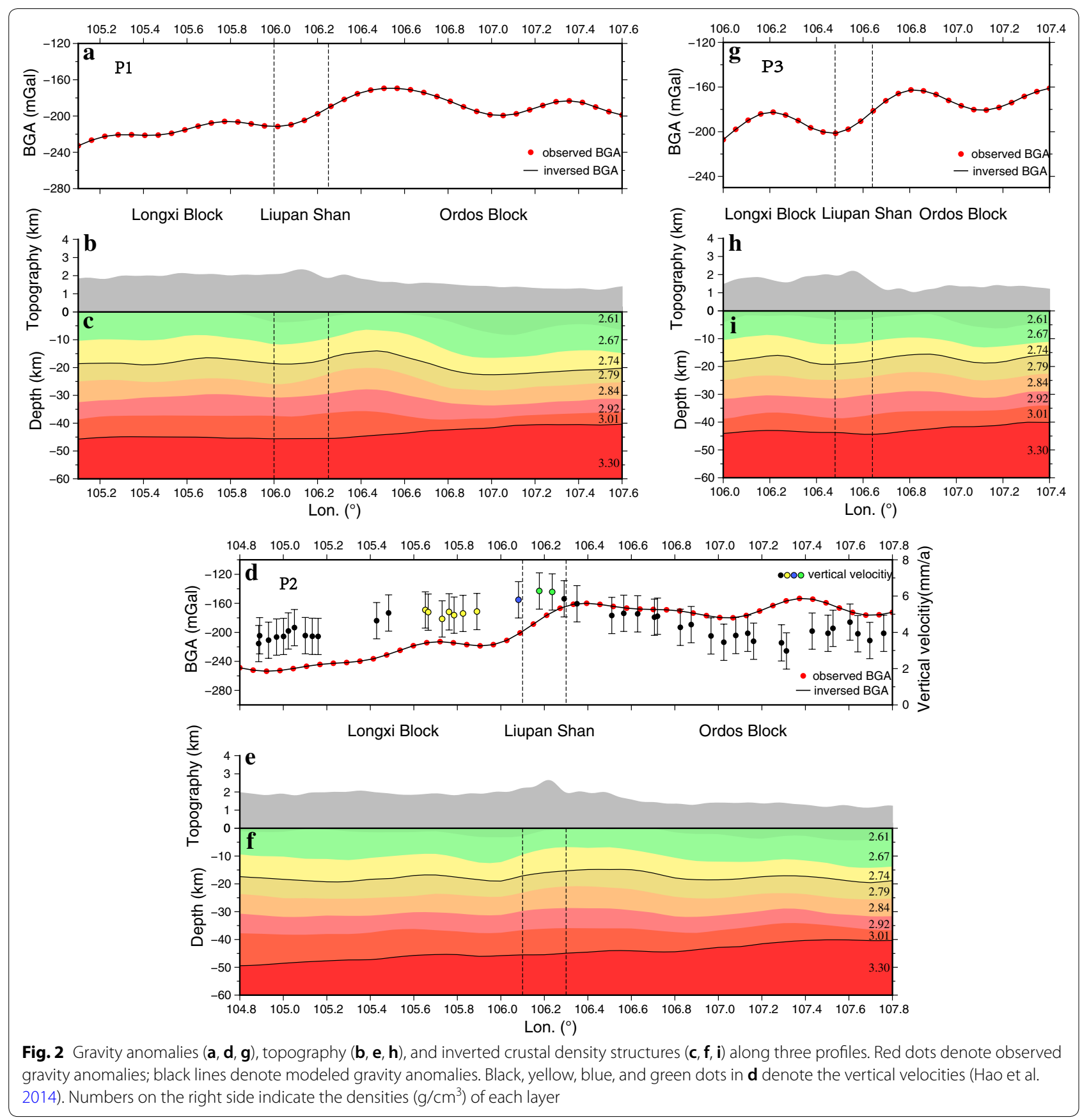

has a conspicuous vertically layered feature, similar to the initial model. The Moho of all three profiles are deep in the west and shallow in the east, indicating that the crust gradually thins from the Tibetan Plateau to the interior. The Moho result is constant and there is no mountain root beneath the Liupan Shan; these results are identical to those of Bao et al. (2013). In this study, the interface between the third and fourth layer is regarded as the interface between the upper and lower crust. In profile
$\mathrm{P} 2$, the interface between the upper and lower crust, which corresponds to low BGAs, is notably concave to the west of the Liupan Shan. This concave shape was also reported in a previous seismic study (Zhou et al. 2000). The shallow low-density layer inside the Ordos Block is very thick, corresponding to the thick sedimentary layer in the Loess Plateau. The inversion results are close to those of Zheng et al. (2010) and in good correspondence with CRUST 1.0. 


\section{Flexural analysis of the Liupan Shan}

To the west of the Liupan Shan, both the BGAs and crustal structures exhibit high-altitude features, which should instead exist beneath the Liupan Shan. The reason for this abnormal phenomenon might be that Liupan Shan was thrusted before it was able to form a complete mountain root. The surface materials were thrusted away rapidly, dragging the underground structures slowly eastward, and the difference between these velocities led to the offset. The premise of this hypothesis is that uplift of the Liupan Shan was caused by oblique subduction of surface materials. In order to verify the hypothesis, we conducted a flexural analysis by the free-air gravity anomaly admittance method.

The gravity admittance method can estimate loading ratios to reveal uplift mechanisms (McKenzie, 2003). In this study, the thickness and density of the upper and lower crust were $18.0 \mathrm{~km}, 26.1 \mathrm{~km}, 2.68 \mathrm{~g} / \mathrm{cm}^{3}$, and
$2.89 \mathrm{~g} / \mathrm{cm}^{3}$, respectively, and the density of the mantle was $3.30 \mathrm{~g} / \mathrm{cm}^{3}$ according to the inverted density structure. Poisson's ratio was 0.25 and Young's modulus was $1.0 \times 10^{11} \mathrm{~Pa}$ (Chen et al. 2013). Figure 3 shows that the misfit between modeled and observed data was a minimum at $T_{\mathrm{e}}=5 \mathrm{~km}, F_{1}=1$, and $F_{2}=F_{3}=0$, where $T_{\mathrm{e}}$ is the effective elastic thickness and $F_{1}, F_{2}$, and $F_{3}$ denote the loading ratios on the Earth's surface and the interface between the upper and lower crust and the Moho to the total loading. This result is consistent with previous research; i.e., She et al. (2016) estimated that $T_{\mathrm{e}}=1 \mathrm{~km}$, $F_{1}=0.95, F_{2}=0.05$ by the same method.

\section{Interpretation and discussion}

The estimate of $T_{\mathrm{e}}=5 \mathrm{~km}$ indicates that the lithosphere of the Liupan Shan (adjacent to Liupan Shan fault) is too weak to suffer thrust and is easily deformed. $F_{1}=1$ indicates that the initial loading comes from surface;
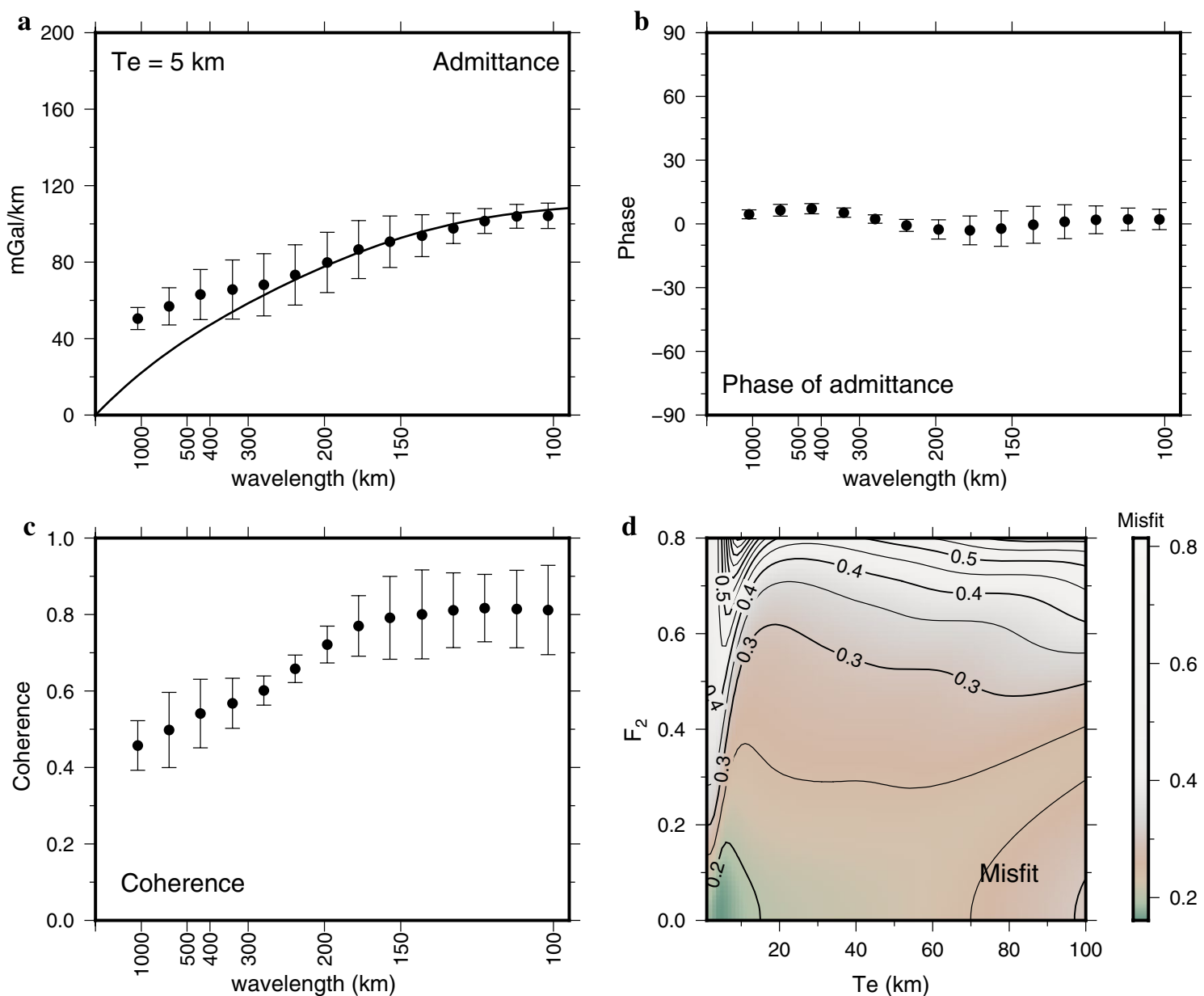

Fig. 3 Flexural analysis using the admittance between the free-air gravity anomaly and the topography. Error bars represent 1 sigma. a Admittance as a function of wavelength, $\mathbf{b}$ complex phase of admittance between gravity and topography in degrees, $\mathbf{c}$ coherence magnitude between gravity and topography, and $\mathbf{d}$ misfit contours when $F_{3}=0$ calculated from modeled and observed admittance values 
i.e., outward growth of the high-altitude area due to oblique subduction was the uplift mechanism of the Liupan Shan, which supports the hypothesis of this study. Figure 3c shows that the coherence between gravity anomaly and topography is high at short wavelengths and low at long wavelengths. A decrease of coherence can arise in two ways; from erosion and from inadequate isostatic compensation. Erosion removes the topography and inadequate compensation means that underground materials are independent of the topography. If the low coherence at long wavelengths was caused by erosion, the spatial scale of erosion would be very large and therefore the coherence should also be low at short wavelengths. However, according to Fig. 3c, the coherence is high at wavelengths less than $150 \mathrm{~km}$; thus, erosion is rejected as the reason for reduced coherence. Conversely, the high coherence at short wavelengths may result from a lack of isostatic compensation, suggesting that the gravity anomaly is a function of the topography. Therefore, we suggest that a lack of compensation occurred at the Liupan Shan on a spatial scale of approximately $150 \mathrm{~km}$, and inadequate compensation occurred at adjacent areas. This finding corresponds to the inverted structure that both Moho and interface between upper and lower crust at the Liupan Shan are flat, indicates that no compensation occurs. In summary, Liupan Shan showed a lack of isostatic compensation and was uplifted due to oblique subduction of surface materials.

The offset between the topography and crustal structure west of the Liupan Shan can be interpreted based on the uplift mechanism and isostatic state. We speculate that the Liupan Shan experienced three key stages of deformation (Fig. 4):
1. In stage 1, the Liupan Shan was thrusted by the Longxi Block, which began the orogeny.

2. In stage 2, the thrust effect weakened or subsided and the orogeny ceased. The Liupan Shan began to isostatically adjust but did not reach complete isostatic equilibrium, leading to a concave interface between the upper and lower crust but a flat Moho.

3. In stage 3, the Liupan Shan was again thrusted and uplifted. It was thrusted rapidly eastward by surface loading, which gradually formed the current geomorphology under the influence of erosion and sedimentation. Conversely, underground structures were dragged slowly and therefore deviated from the topography. This process explains the formation of the offset between crustal structure and topography as well as the partial isostatic compensation.

The above evolution process has not been validated. Moreover, as it was deduced from static gravity and GPS data, it does not provide precise dates for these events. However, many chronology and geodesy analysis results support this hypothesis. Wang et al. (2011) suggested that the Liupan Shan-Haiyuan fault system was tectonically quiescent from approximately $29-10.5 \mathrm{Ma}$ and began to uplift at $10.5 \mathrm{Ma}$. We consider that these quiescence and uplift events correspond to stage 2 and 3, respectively. Li et al. (2013) analyzed electron spin resonance data and suggested that the Liupan Shan has experienced a series of NW-SE compression, near E-W extension, and NESW compression events since the Cenozoic. Compressional stress is related to thrusting of the Longxi Block and extensional stress can be interpreted by the variations of gravitational potential energy (GPE). It is worth pointing out that the effect of mantel convection and plate traction on horizontal tectonic stress is much larger

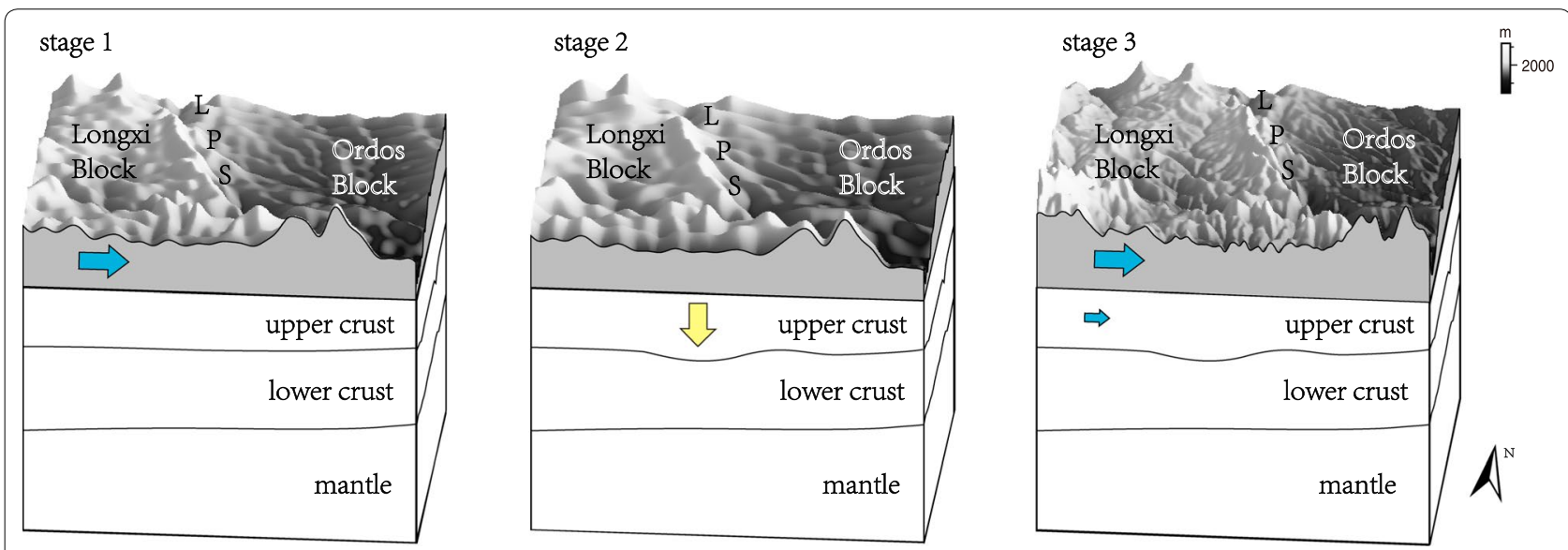

Fig. 4 Sketch showing the evolution and uplift of the Liupan Shan. Blue arrows denote thrusting or dragging directions. Yellow arrow denotes the direction of isostatic adjustment. Large arrows denote major motion, whereas small arrows denote minor motion 
than that of GPE at northeast Tibetan Plateau. Only in particular situation, like stage 2 proposed in this work, the inhomogeneous distribution of GPE caused by different topographies can be regarded as the major source of stress (Ghosh et al. 2013). Areas with high GPE would show extensional stress, whereas low GPE areas would exhibit compressional stress. In stage 2, thrusting of the Longxi Block subsided and the materials accumulated during stage 1 in the Liupan Shan began to expand to western and eastern areas with low latitude. As a result, the Liupan Shan showed E-W extensional stress in stage 2 .

Furthermore, Li et al. (2017) processed GPS data from a dense network of stations in the northeast Tibetan Plateau during 1999-2016 and found that the thrusting component of the Liupan Shan fault was approximately $2.9 \pm 1.2 \mathrm{~mm} / \mathrm{a}$. Zhao et al. (2017) suggested that shortening rate of the Liupan Shan fault was $3.0 \pm 1.1 \mathrm{~mm} / \mathrm{a}$ based on GPS data from 1998-2014. In this study, we assume that the shortening rate is identical to the movement velocity of the Liupan Shan, and the initial time of movement corresponds to the initial time of stage 3, which was $12 \mathrm{Ma}$ ( $\mathrm{Li}$ et al. 2013). Thus, the estimated amount of Liupan Shan movement since stage 3 is $36 \pm 13.2 \mathrm{~km}$, which is very close to the $34 \mathrm{~km}$ offset between the peak altitude in the Liupan Shan and the low BGA values.

The crust should rebound if loadings were removed or surface materials were thrusted; i.e., west of Liupan Shan should exhibit a faster uplift rate than other areas. Hao et al. (2014) suggested that the velocity at west of Liupan Shan $(5.8 \mathrm{~mm} / \mathrm{a}$, blue dot in Fig. 2d) is higher than those at other areas (for instance, $5 \mathrm{~mm} / \mathrm{a}$, yellow dots in Fig. 2d), except for the maximum velocity at the highest altitude in the Liupan Shan $(6.2 \mathrm{~mm} / \mathrm{a}$, green dots in Fig. 2d) due to the orogeny. The faster rate of the blue dot indicates rebound. In summary, both chronological and geodetic analyses agree with the tectonic evolution process of the Liupan Shan mountains proposed in this study.

\section{Conclusions}

Using gravity and GPS measurements around the southwest margin of the Ordos Block from 2014 and 2017, we inverted the crustal density structures of three profiles across the Liupan Shan and then performed flexural analysis. The findings of this study provide insights into the uplift and tectonic evolution of Liupan Shan and adjacent areas. The main findings are summarized below:

1. The Liupan Shan is located in a BGA transitional zone. The mean BGAs of the western part are -216.7 $\mathrm{mGal},-231.3 \mathrm{mGal}$, and $-193.5 \mathrm{mGal}$ for the three profiles, whereas those of the eastern part are -185.3 $\mathrm{mGal},-167.9 \mathrm{mGal}$, and $-170.4 \mathrm{mGal}$, respectively.

2. Low BGAs do not correspond to the peak altitude region of the Liupan Shan but to the area further west. No mountain root is observed beneath the Liupan Shan, but the interface between the upper and lower crust is notably concave to the west. The offset between low BGAs and peak of the Liupan Shan is clearest in profile P2, where it reaches a maximum of $34 \mathrm{~km}$.

3. The flexural analysis results indicate that the effective elastic thickness is $5 \mathrm{~km}, F_{1}=1$, and $F_{2}=F_{3}=0$, suggesting that uplift is due to the oblique subduction of surface materials. The coherence results indicate that the offset is caused by a lack of isostatic compensation.

4. According to the BGA, crustal structure, and flexural analysis results, we propose a three-stage tectonic evolution process for the Liupan Shan. In stage 1, the Liupan Shan was thrusted by the Longxi Block, which began the orogeny. In stage 2, the thrust effect subsided, Liupan Shan began to isostatically adjust but did not reach isostatic equilibrium, and a concave interface appeared between the upper and lower crust but not in the Moho. In stage 3, the Liupan Shan was again uplifted and thrusted rapidly eastward by surface loading, whereas underground structures were dragged more slowly, resulting in the observed offset from surface topography.

\section{Supplementary information}

Supplementary information accompanies this paper at https://doi. org/10.1186/s40623-019-1127-2.

Additional file 1. Topography and reference models of profile DD'from Bao et al. (2013) and profiles P1-3. Numbers indicate the densities (g/ $\mathrm{cm}^{3}$ ) of each layer. The reference models of profiles P1-2 are derived from the "profile propagation" method and that of P3 is interpolated from the inverted models. The differences between inverted and reference model of each profile are small for the reason that we require these models to be close.

\section{Abbreviations}

BGA: Bouguer gravity anomaly; Te: effective elastic thickness; LPS: Liupan Shan mountains; LPSF: Liupan Shan fault; LBF: Longxian-Baoji fault; NQF: North Qinling fault; WF: Weihe fault; WQF: Western Qinling fault; LTF: Lintan-Tanchang fault; HF: Haiyuan fault; WRB: West Region Block; NAB: Northeast Asia Block; NCB: North China Block; SCB: South China Block; TP: Tibetan Plateau; CBB: China-Burma Block; GPE: gravitational potential energy.

\section{Acknowledgements}

The authors acknowledge the use of the International Centre for Global Earth Models and the Geospatial Data Cloud. 


\section{Authors' contributions}

ZW conducted the analysis and wrote the paper. GF guided this study as the graduate-course supervisor of ZW. Both authors read and approved the final manuscript.

\section{Funding}

This work was supported financially by the National Natural Science Foundation of China (41874003 and 41574071).

\section{Availability of data and materials}

The data used in this study are available from the International Centre for Global Earth Models (http://icgem.gfz-potsdam.de/home) and the Geospatial Data Cloud (http://www.gscloud.cn/).

\section{Ethics approval and consent to participate}

Not applicable.

\section{Consent for publication}

Not applicable.

\section{Competing interests}

The authors declare that they have no competing interests.

\section{Author details}

${ }^{1}$ Institute of Geophysics, China Earthquake Administration, Beijing 100036, China. ${ }^{2}$ Institute of Earthquake Forecasting, China Earthquake Administration, Beijing 100081, China.

Received: 3 November 2019 Accepted: 26 December 2019 Published online: 02 January 2020

\section{References}

Bao X, Song X, Xu M, Wang L, Sun X, Mi N et al (2013) Crust and upper mantle structure of the North China Craton and the NE Tibetan Plateau and its tectonic implications. Earth Planet Sci Lett 369:129-137. https://doi. org/10.1016/j.epsl.2013.03.015

Chen B, Chen C, Kaban MK, Du J, Liang Q, Thomas M (2013) Variations of the effective elastic thickness over China and surroundings and their relation to the lithosphere dynamics. Earth Planet Sci Lett 363:61-72. https://doi. org/10.1016/j.epsl.2012.12.022

England P, Houseman G (1989) Extension during continental convergence, with application to the Tibetan Plateau. J Geophys Res Solid Earth 94(B12):17561-17579. https://doi.org/10.1029/JB094iB12p17561

Fu G, Gao S, Freymueller JT, Zhang G, Zhu Y, Yang G (2014) Bouguer gravity anomaly and isostasy at western Sichuan Basin revealed by new gravity surveys. J Geophys Res Solid Earth 119(4):3925-3938. https://doi. org/10.1002/2014JB011033

Ghosh A, Holt WE, Wen L (2013) Predicting the lithospheric stress field and plate motions by joint modeling of lithosphere and mantle dynamics. J Geophys Res Solid Earth 118(1):346-368. https://doi.org/10.1029/2012J B009516

Hao M, Wang Q, Shen Z, Cui D, Ji L, Li Y, Qin S (2014) Present day crustal vertical movement inferred from precise leveling data in eastern margin of Tibetan Plateau. Tectonophysics 632:281-292. https://doi.org/10.1016/j. tecto.2014.06.016

Harrison TM, Copeland P, Kidd WSF, Yin A (1992) Raising tibet. Science 255(5052):1663-1670. https://doi.org/10.1126/science.255.5052.1663

Kutzbach JE, Prell WL, Ruddiman WF (1993) Sensitivity of Eurasian climate to surface uplift of the Tibetan Plateau. J Geol 101(2):177-190. https://doi. org/10.1086/648215

Li Y, Oldenburg DW (1998) 3-D inversion of gravity data. Geophysics 63(1):109_ 119. https://doi.org/10.1190/1.1444302

Li W, Dong Y, Guo A, Liu X, Zhou D (2013) Chronology and tectonic significance of Cenozoic faults in the Liupanshan Arcuate Tectonic Belt at the northeastern margin of the Qinghai-Tibet Plateau. J Asian Earth Sci 73:103-113. https://doi.org/10.1016/j.jseaes.2013.04.026

Li Y, Shan X, Qu C, Zhang Y, Song X, Jiang Y et al (2017) Elastic block and strain modeling of GPS data around the Haiyuan-Liupanshan fault, northeastern Tibetan Plateau. J Asian Earth Sci 150:87-97. https://doi. org/10.1016/j.jseaes.2017.10.010

Liang M, Wang Z, Zhou S, Zong K, Hu Z (2014) The provenance of Gansu Group in Longxi region and implications for tectonics and paleoclimate. Sci China Earth Sci 57(6):1221-1228. https://doi.org/10.1007/s1143 $0-013-4787-y$

Marquardt DW (1963) An algorithm for least-squares estimation of nonlinear parameters. J Soc Ind Appl Math 11(2):431-441. https://doi. org/10.1137/0111030

Laske G, Masters, G, Ma Z, Pasyanos M (2013) Update on CRUST1.0_a 1-degree global model of earth's crust. Geophys Res Abstracts, 15, Abstract EGU2013-2658

McKenzie D (2003) Estimating $T_{e}$ in the presence of internal loads. J Geophys Res Solid Earth. https://doi.org/10.1029/2002JB001766

Molnar P, Tapponnier P (1975) Cenozoic tectonics of Asia: effects of a continental collision. Science 189(4201):419-426. https://doi.org/10.1126/scien ce.189.4201.419

Royden LH, Burchfiel BC, King RW, Wang E, Chen Z, Shen F, Liu Y (1997) Surface deformation and lower crustal flow in eastern Tibet. Science 276(5313):788-790. https://doi.org/10.1126/science.276.5313.788

She Y, Fu G, Su X, Meng G, Zhu Y, Guo S (2016) Crustal isostasy and uplifting mechanism of the Liupanshan area. Progr Geophys 31(4):1464-1472. https://doi.org/10.6038/pg20160408 (in Chinese)

Shen X, Liu M, Gao Y, Wang W, Shi Y, An M et al (2017) Lithospheric structure across the northeastern margin of the Tibetan Plateau: implications for the plateau's lateral growth. Earth Planet Sci Lett 459:80-92. https://doi. org/10.1016/j.epsl.2016.11.027

Song Y, Fang X, Li J, An Z, Miao X (2001) The Late Cenozoic uplift of the Liupan Shan, China. Sci China Ser D Earth Sci 44(1):176-184. https://doi. org/10.1360/yd2001-44-S1-176

Talwani M, Worzel JL, Landisman M (1959) Rapid gravity computations for two-dimensional bodies with application to the Mendocino submarine fracture zone. J Geophys Res 64(1):49-59. https://doi.org/10.1029/JZ064 i001p00049

Tapponnier P, Zhiqin X, Roger F, Meyer B, Arnaud N, Wittlinger G, Jingsui Y (2001) Oblique stepwise rise and growth of the Tibet Plateau. Science 294(5547):1671-1677. https://doi.org/10.1126/science.105978

Wan Y, Xie H, Yang H, Wang Z, Liu D, Kröner A et al (2013) Is the Ordos block Archean or Paleoproterozoic in age? Implications for the Precambrian evolution of the North China Craton. Am J Sci 313(7):683-711. https://doi. org/10.2475/07.2013.03

Wang W, Zhang P, Kirby E, Wang L, Zhang G, Zheng D, Chai C (2011) A revised chronology for tertiary sedimentation in the Sikouzi basin: implications for the tectonic evolution of the northeastern corner of the Tibetan Plateau. Tectonophysics 505(1-4):100-114. https://doi.org/10.1016/j.tecto 2011.04 .006

Wang X, Fang J, Hsu H (2014) Three-dimensional density structure of the lithosphere beneath the North China Craton and the mechanisms of its destruction. Tectonophysics 610:150-158. https://doi.org/10.1016/j.tecto 2013.11 .002

Wang Z, Fu G, She Y (2018) Crustal density structure, lithosphere flexure mechanism, and isostatic state throughout the Qinling Orogen revealed by in situ dense gravity observations. J Geophys Res Solid Earth 123(11):10-026. https://doi.org/10.1029/2018JB016117

Wu J, Guo L, Xiong S, Wang S, Tang Z, Jin C et al (2019) New magnetic constraints on early-middle Miocene uplift of the Liupan Shan, northeastern margin of the Tibetan Plateau. Geochem Geophys Geosyst 20(3):13401357. https://doi.org/10.1029/2018GC007944

Zhang P, Burchfiel BC, Molnar P, Zhang W, Jiao D, Deng Q et al (1991) Amount and style of late cenozoic deformation in the Liupan Shan area, Ningxia autonomous region, China. Tectonics 10(6):1111-1129. https://doi. org/10.1029/90TC02686

Zhang Y, Teng J, Wang Q, Lü Q, Si X, Xu T et al (2017) A gravity study along a profile across the Sichuan Basin, the Qinling Mountains and the Ordos Basin (central China): density, isostasy and dynamics. J Asian Earth Sci 147:310-321. https://doi.org/10.1016/j.jseaes.2017.07.036

Zhao B, Zhang C, Wang D, Huang Y, Tan K, Du R, Liu J (2017) Contemporary kinematics of the Ordos block, North China and its adjacent rift systems constrained by dense GPS observations. J Asian Earth Sci 135:257-267. https://doi.org/10.1016/j.jseaes.2016.12.045 
Zheng D, Zhang PZ, Wan J, Yuan D, Li C, Yin G et al (2006) Rapid exhumation at $8 \mathrm{Ma}$ on the Liupan Shan thrust fault from apatite fission-track thermochronology: implications for growth of the northeastern Tibetan Plateau margin. Earth Planet Sci Lett 248(1-2):198-208. https://doi. org/10.1016/j.epsl.2006.05.023

Zheng Y, Yang Y, Ritzwoller MH, Zheng X, Xiong X, Li Z (2010) Crustal structure of the northeastern Tibetan plateau, the Ordos block and the Sichuan basin from ambient noise tomography. Earthq Sci 23(5):465-476. https:// doi.org/10.1007/s11589-010-0745-3
Zhou MD, Lü TY, Zhang YS, Ruan AG (2000) The geological structure background and the crustal structure in the northeastern margin of the Qinghai-Tibetan Plateau. Acta Seismol Sin 13:687-697. https://doi. org/10.1007/s11589-000-0071-2

\section{Publisher's Note}

Springer Nature remains neutral with regard to jurisdictional claims in published maps and institutional affiliations.

\section{Submit your manuscript to a SpringerOpen ${ }^{\circ}$ journal and benefit from:}

- Convenient online submission

- Rigorous peer review

- Open access: articles freely available online

- High visibility within the field

- Retaining the copyright to your article

Submit your next manuscript at $\boldsymbol{\nabla}$ springeropen.com 